\title{
Study on the Cultural Inheritance and Dissemination of Japanese Animation
}

\author{
Qin Wang ${ }^{1, a}$ \\ ${ }^{1}$ College of Foreign Languages, Yanan University, Yanan, Shanxi, 716000 \\ ${ }^{a}$ email
}

Keywords: Japanese Animation; Cultural Heritage; Spread

\begin{abstract}
Japanese anime reflect its unique culture, aesthetic awareness and artisan spirit world was widely praised. Japan's first animation from the United States, from the beginning of the "ism" to their own culture into a commodity chain, after decades of development has become more sophisticated, forming a unique artistic and cultural characteristics of the character and the arts Communications Trend, thus becoming part of the world of popular culture. From the perspective of cultural communication, studies can illustrate the spread of cultural heritage and Japanese anime.
\end{abstract}

\section{Introduction}

As a world famous DreamWorks animation, anime amount of playing Japan occupied more than sixty percent of the world. In Japan, you can see the animation elements have become an integral part of Japanese life. Japanese anime culture has become one of the symbols of Japan. Japanese animation is from start to gradually form a complete industrial chain business, to develop into a global influence industry after decades of change. Japanese animation culture is known as the Japan charming "cultural autonomy." In 2000 the Japanese Ministry of Education of animation into the tea ceremony, kabuki, sumo, Japan's fourth "national treasure." Development of Japanese comics industry, mainly for the original cartoon and then animate, gamification, derivative products, the formation of a powerful industry chain, resulting in huge economic benefits.

\section{The Origin of Japanese Anime}

Japanese animation and comics collectively. Origin of Japanese comics, according to the relevant literature, the earliest form of Japanese comic concept, is safe from the late (12 century) to the Kamakura period (13 century) during the production of "birds show map" (The author is a legend Toba monk positive), Edo period appears "Hokusai manga" (Katsushika Hokusai, 1814), to further improve the comic meaning it can be said to be the originator of modern comics.

"Edo Porn" compared to the "birds show map", in the form of performance more broadly, and "birds show map" performance was "funny", "strange", forms relatively simple, while the "Edo Porn" is not only grouping the "birds show map" forms, but also enriched the connotation of the performance and content of modern Japanese manga "game" theme similarity. Secondly Katsushika Hokusai also boldly used the word "comic." The word for comics, a lot of the literature is generally recognized Hokusai created. With the development of Japanese society has experienced several dynasties alternate history, people's living way from the material culture of pursuing a gradual transition to spiritual pursuits, needs to be more abundant spiritual food. Comics because of its simplicity, the public has become an important way to express emotion, people's emotional expression manifested in the form of comics that popular culture.

Japanese comics industry is closely related to prosperity and social environment. Tokugawa shogunate was established from the beginning of the Edo period lasted for 264 years (1603-1867) of peace and prosperity. During this period, nearly 250 years time no major war, civilian culture has been greatly developed (later known as long cultural celebration), because social peace, people's living and production has been greatly restored, there are a lot of time for a variety of recreational 
activities and cultural performances, and this time the Japanese started the process of urbanization, the urbanization process in the civilian sectors to improve the level of consciousness and the Japanese manga door policy has been the development of buffer. 1817 appeared to "comic" named portfolio, such as Ogata Korin "light Lin comics." 1885 years aryl Gang's "comic aryl years." The cartoons have inherited the spirit of Hokusai's painting, "casual painting" feature is very strong, but no breakthrough in style and place.

\section{The Development of Japanese Anime}

Development of Japanese anime fully embodies the spirit of the island: in the country on the basis of absorbing foreign concept to adapt and improve output abroad. With Japan's animation industry continues to mature, excellent animation works endless, story and style not only inherits the excellent traditional Japanese culture, and innovative on this basis. Japanese animation accounted for most of the country's cultural industry, cultural industry chain has become Japan's very critical part. Japan's animation industry from generation to total development experienced three stages of development, these three periods of Japanese anime electronic post-production basis.

Infancy (1917 Year - 1945). Japanese anime this period, due to the impact of foreign culture, the invasion of foreign ideas to make the subject of animation culture of Japan focused on the world classics. French naturalist movement on this case Japanese animation house large cartoonist eyes cast on the world of animation, the show is the world's culture. Late infancy, the factors leading to the war in Japan's militarism prevalent, animation theme reflected in advocacy and boast Japanese militarism works, and thus provoke domestic public enthusiasm for war. For example, in 1932 the Japanese launched the "magic of the sea" is a theme of militarism animation for the development of Japanese animation later laid the army color.

The exploration period (1945 Year - 1952). Affected by the defeat of the Japanese domestic economy and culture exhibit depressed state, Japan, as the evil fascist supporting one side, by the criticism from the international community, the Japanese animators international form, the anti-war factors applied to the anime show a peace-loving side and brutal side of the war, this theme is supported by the community. For example in 1974, Reiji Matsumoto responsible for the script and the character of "Space Battleship" staged, aroused a sensation, resulting in "Reiji Matsumoto Tornado" broke out in Japan first animation heat. Japanese anime has made great breakthroughs, but also means that Japanese animation production technology matures.

Maturity (1982 - present). 1982 Japanese release of "Macross", marking the Japanese anime entered a mature period, a variety of painting techniques and production technology is mature, has been praised all walks of life, the iconic anime started to become a symbol of Japanese culture. Japan's professional animation production team began to mature, into a modern commercial elements of Japanese animation into the present flag commercial factors in 1935 "New Century" Anno Hideaki director, marking the animation culture into modern business culture, commercial elements use for the animation industry has brought huge economic benefits, Japan began to squeeze into the international animation culture industry chain, to become the second after the US animation industry giants. Japanese anime also extends the maturity of some new pop culture and business opportunities, such as "Cosplay" culture, meaning "role-playing" generally refers to a specific anime fans wearing costumes to play animation, video games and some of the figures. This requires clothing, jewelry, hair accessories, and thus boost the development of related industries, and now many countries in the world are held Animation Festival, "Cosplay" is the theme of the show home star animation festival, it will be through the purchase of related cosplay products, play their favorite cartoon characters, such as "Naruto", "Fruits Basket" and "Inuyasha" and other figures.

\section{The Japanese Anime Inheritance and Its Propagation}

Advances in technology development is inseparable from the Japanese animation industry, compared to the traditional paper printing, video communication now more used, the use of new 
media will combine sound picture to the audience a better visual experience, transmission animation and more to diversify. Japanese anime distinctive cultural features and the cartoonists generation artisan spirit of tradition, the Japanese anime continuity is maintained and sophisticated production processes and a high level of production standards.

The transmission diversity. Japan by the Meiji Restoration, ending the rule of the Tokugawa shogunate, breaking the nearly three hundred years of a policy of seclusion, began to actively learn and absorb Western culture, the introduction of European art good idea. Regular issuance of newspapers, magazines form a prototype now publishing, newspaper and other circulation system. According to statistics, the first professional cartoonist for the Rakuten Kitazawa (1876-1955), studied European and American comics, is active from the Meiji to Showa era cartoonist, painter. In "News Comics", "Tokyo package" and other newspapers as the center, he published a large number of political cartoons and folk cartoons. Organized and launched "Comic good music would," cartoonist for the training of junior made a significant contribution. Many researchers say Comics Lotte as "Modern Japanese comic originator." Serialized in magazines happen text types will Japanese anime culture to a new historical high, 1862 Charles on the creation of "Japan Polyster nn chi ', as the British in July 1841 founded the" Punch, or The London Chari vari "of derived magazine. At the same time, "Polyster nn chi" also become a cartoon called, which is Japan's first manga magazine. 1915, cartoonist, a flat lyricist Okamoto (1886-1948) organized and set up Japan's first cartoonist group - Tokyo will Comics, Graphic Novels he serialized "human life" in "Tokyo Asahi Shimbun" on for the modern comic story to shape the initial prototype form. A large number of newspapers, publishing houses set up for comic spread an important role in Japan's mature printing systems, in the spread of mass media, the harvest of broad domestic and foreign markets.

Local culture vividness. A remarkable feature of Japanese anime is integrated into the traditional cultural elements of the Japanese mainland, with distinctive ethnic characteristics. Meng house system, otaku culture, the second element and other elements of contemporary culture in Japan full of anime and animation industry has become a buzzword. Japanese animation themes not significantly limited, cultural atmosphere is relatively relaxed. The cartoonist comic theme needed to reflect changes in the Japanese public favor, rituals and folk customs of themes, such as "Crayon", is the Japanese general description of traditional family life and corresponding with Japan festival, customs form with "a turban." Japanese anime expression distinctive Japanese cultural characteristics drawn from a rich beginning of a single theme to the modern militarism, also provided material for many industrial design. As every contemporary literary works are a true reflection of their social life and culture, Japanese animation is a map of Japanese culture can be seen through the Japanese anime culture psychology. Japanese thinker Masao Maruyama noted, "Even the Japanese bushido spirit of profound influence God, is nothing more than the integration of Confucian culture and Buddhist culture. As for the moral doctrine in the strict sense, the teachings of Confucius is the most abundant of the origin of Bushido . "from the" One Piece "this movie, we can see that both the so-called Japanese Bushido spirit can also be seen in Europe and America adventure and individualism, while China's Confucian culture, Oriental usual order, collective conceptualism and hierarchy, is a more complete reflection of Japanese culture of anime. Healing famous anime "Natsume's Book of Friends", reflects the Japanese nature worship and awe, it reflects their spiritual beliefs and animist statement. It also relates to Japan's unique "moral principles" cultural and ideological gratitude.

Artisan spirit Inheritance. Japanese comics mentioned, it is impossible to bypass the Osamu Tezuka. From his youth he witnessed World War II brought the ruins to his later saying: "Now, the times we live in, like a comic air." Between 40 years of comic career, he set the tone for future generations of animation, advice, comics from a variety of children's books developed into a narrative story of all ages, he completed a few people a lifetime to complete the work, is the real "the animation God. " After appearing Miyazaki, it can be called "the epitome of the spirit of the artisan." From 1943 began his career, Miyazaki has been stubbornly with a brush, hand-drawn animated movie. His body is with the most typical temperament as craftsmen. That is for their craft have an almost arrogant self-esteem, and to that end the trouble, at all costs, just to achieve 
excellence. His works express not only animated, more ponder life. Miyazaki can be said to be a legendary Japanese animation industry, he was the first to rise to the animation Humanistic height thinker, but also three generations of Japanese animation home the past and the spiritual pillar. Each of his works, although the subject matter is different, but it will be a dream, environmental protection, life, survival of these are reflective message which fusion.

Japanese anime can be focused precisely because of this kind of spontaneous generation to generation comic heritage, such as "My Hero Academy" Kohei of Horikoshi, the year he was praised and encouraged the contribution comic "One Piece" by Eiichiro Oda 13 years after Horikoshi can finally take his own works and Oda comic strip of the same magazine. And then it was Oda Yoshihiro Togashi fancy, and later grow into pillars Jump cartoonist. Japanese anime no fault in the transmission process, which is closely related with the animation house painting skills and their continued diligence strictly adhere to the spirit of the artisan. Japanese anime mainly through the exquisite painting techniques, giving the audience a good visual effect, the pursuit of sensual human factors, the Japanese cartoon animation team play throughout the sense of speed, dynamism, there are stringent requirements, even the montage approach is also used in them. A good anime needs of individual departments continue cooperation in order to produce public effects. Japanese craftsmen culture animation reflected most vividly.

\section{Conclusion}

Japanese animation development has led Japan into country which has a similar power in cultural exports with US. More influence within a miracle can be used to describe. Since the new century, the development of animation has become more diverse, many new animation culture began to rise, such as the Department of the harem, tear lines, SM, BL Department, GL system and the like, each area has some fanatical supporters. Anime began to move closer to work fast-food entertainment, and truly unique, meaning there is less and less work, many classic up the scene or until golden age. Therefore, the cultural heritage and promote Japanese anime is more urgent, the future is a subject worthy of careful consideration.

\section{References}

[1] Liu Ying. Inheritance and Innovation. - Analysis of Japanese animation in the traditional culture [J]. Art and Design (theory), 2013 (09).

[2] Cui Lei, Li Xiangdong. Animation: flexible policy of mass media in Japan [J] Contemporary Communications, 2007 (6): 60-62.

[3] Tian Shasha. New Japanese Construction - the Japanese anime Cultural based on Context of Globalization [D]. East China Normal University, 2008.

[4] Liu Yanping. Context of Globalization of Japanese anime culture propagation and cultural infiltration [D]. Zhengzhou University, 2013.

[5] Ledoux, Trish, ed. Ainme If lterviews: The first FVIeeYars of Ainmeirca, Ainme and Magamon this (1992 a 97) [M]. Sanfrancisco: Vizconunll inciatons, 1997: 31 a 32.

[6] Chen Qi. Spread of Japanese animation in China's cross-cultural [J]. Northwest humanities comments, 2008 (12): 41-43.

[7] Chen Qijia. Japanese anime Introduction to Art [M]. Shanghai: Shanghai Jiaotong University Press, 2006: 97-98. 